\title{
Comparative Response of CRL-11372 Cells to Surface Roughness and Crystalline Structure of the Surfaces Developed by Sandblasting, Etching, and $\mathrm{TiO}_{2}$ Coating on Commercially Pure Ti Discs
}

\author{
Sinem Yeniyol'1, Bahadır Kepenek ${ }^{2}$, Ayhan Bilir³, Ali Fuat Çakır², Nilüfer Bölükbaşı1, \\ Mefail Yeniyol $^{4}$, Tayfun Özdemir ${ }^{1}$ \\ ${ }^{1}$ Department of Oral Implantology, Faculty of Dentistry, Istanbul University, Istanbul, Turkey \\ ${ }^{2}$ Department of Metallurgical and Materials Engineering, Faculty of Chemical and Metallurgical Engineering, \\ Istanbul Technical University, Istanbul, Turkey \\ ${ }^{3}$ Department of Histology and Embryology, Faculty of Medicine, Istanbul University, Istanbul, Turkey \\ ${ }^{4}$ Department of Geological Engineering, Faculty of Engineering, Istanbul University, Istanbul, Turkey \\ Email: yeniyols@istanbul.edu.tr
}

Received 20 January 2014; revised 26 February 2014; accepted 19 March 2014

Copyright (C) 2014 by authors and Scientific Research Publishing Inc.

This work is licensed under the Creative Commons Attribution International License (CC BY).

http://creativecommons.org/licenses/by/4.0/

(c) (i) Open Access

\section{Abstract}

The aim of this study was to evaluate the adhesion of human fetal osteoblast cells (CRL-11372) in vitro at $24 \mathrm{~h}$ on commercially pure titanium (cp Ti) metal surfaces' crystalline structure and surface roughnesses that are modified by polishing, sand blasting (with alumina $\left(\mathrm{Al}_{2} \mathrm{O}_{3}\right)$ ), sand blasting and coating (with titanium oxide $\left(\mathrm{TiO}_{2}\right)$ ), and sand blasting and etching (with oxalic acid). Modified surfaces were characterized quantitatively by a non-contacting optical profilometer in terms of their $R_{z}$ and $R_{a}$ values and surface profile diagrams were obtained. These surfaces were characterized qualitatively by scanning electron microscope (SEM) micrographs. The crystalline structures of the coatings were characterized by X-ray diffraction (XRD). CRL-11372 cells were cultured for $24 \mathrm{~h}$ and evaluated for their mean total cell counts. Cell morphologies were examined by SEM micrographs. Data were compared by Kruskal-Wallis test followed by Post Hoc LSD test comparisons. SEM micrographs showed variations among the topographies of the surfaces and the morphologies of the cells adhered to these four different surfaces. Cell adhesion was affected by neither Ti chemical composition nor surface roughness within the $R_{a}$ and $R_{z}$ parameters used.

How to cite this paper: Yeniyol, S., Kepenek, B., Bilir, A., Çakır, A.F., Bölükbaşı, N., Yeniyol, M. and Özdemir, T. (2014) Comparative Response of CRL-11372 Cells to Surface Roughness and Crystalline Structure of the Surfaces Developed by Sandblasting, Etching, and $\mathrm{TiO}_{2}$ Coating on Commercially Pure Ti Discs. Materials Sciences and Applications, 5, $245-257$. http://dx.doi.org/10.4236/msa.2014.55029 


\section{Keywords}

\section{Dental Implants, Surface Roughness, Crystalline Structure, Osteoblasts, Cell Adhesion}

\section{Introduction}

Immediate implant placement, immediate loading, and use of one stage implant placement procedures have increased the need for newly innovated dental implant surface properties for replacing missing teeth. Implant surface properties, such as chemical composition and texture, a combination of topography and roughness are believed to affect the cell responses [1]-[5]. Recently, bioengineering for roughening pure titanium implants have gained attention. Surface roughness is an important factor in establishing connection between dental implants and host bone tissue. It was shown to be directing the proliferation and morphology of the osteoblasts [6] [7]. Dental implant surfaces can be modified by several subtractive and additive methods which alter the surface morphology and chemical composition in order to change cells' responses. Mechanical processes as sandblasting or chemical processes, such as etching provide concave surface topographies while hydroxyapatite (HA), titanium plasma spray (TPS), physical vapor deposition (PVD) and chemical vapor deposition (CVD) coating processes provide convex surface topographies [8]. In sandblasting, particles like $\mathrm{Al}_{2} \mathrm{O}_{3}$, titanium oxide, glass, calcium phosphate, soluble blasting particles and ruby in different grain sizes are applied to the surfaces at varying pressures to remove the surface material [9]-[20]. Different acid solutions had been used, such as HF, $\mathrm{HCl} / \mathrm{H}_{2} \mathrm{SO}_{4}$, combinational dual acid etching with $\mathrm{HF} \& \mathrm{HCl} / \mathrm{H}_{2} \mathrm{SO}_{4}$, and $\mathrm{HNO}_{3}$ at a wide body of literature [18] [21]-[24]. PVD is also another surface modification method which leads film growth between a substrate surface and an adjacent vapor generated from a target and transported to the substrate's surface providing a newly formed surface quality maintaining the mechanical properties of the bulk Ti substrate [25].

Osteoblast-like cell attachment, behavior and protein adsorption from serum up to $24 \mathrm{~h}$ on metal (oxide) surfaces comprising variations in chemistry indicated that effects of charge may be mediated by differential protein adsorption to the different metals on the micropatterned surfaces [26]. Higher roughness values were claimed to improve attachment and proliferation, while lower roughness values committed the cell to differentiation [27]. However, the ideal crystalline structure and value of surface roughness for the optimal bone-implant contact remains unknown and in vitro biocompatibility of the surface-modified titanium surfaces need to be evaluated in terms of the cell responses in contact with them.

The aim of this in vitro study was to evaluate the effect of surface roughnesses and crystalline structures of modified surfaces on CRL-11372 cells' morphological behavior and adhesion after $24 \mathrm{~h}$.

\section{Materials and Methods}

\subsection{Sample Preparation}

A total of 16 commercially pure Ti discs (grade 2, Friadent GmbH, Mannheim, Germany) measuring $10 \mathrm{~mm}$ in diameter and $2 \mathrm{~mm}$ in thickness were grounded and polished up to a $1 \mu \mathrm{m}$ diamond abrasive suspension with metallurgical papers to obtain a mirror finish surface using Struers RotoSystem (Struers, Glasgow, England).

Four groups (each $n=4$ ) of surface-modified Ti discs were prepared and characterized as follows:

- Polished surfaces (P): Polished Ti discs.

- Sandblasted surfaces (S): Sandblasted Ti discs. $\mathrm{Al}_{2} \mathrm{O}_{3}$ particles of $800 \mu \mathrm{m}$ grain size under a pressure of 6 bars were used for sandblasting. Distance from the discs to the jets was approximately $10 \mathrm{~cm}$, and the $\mathrm{Al}_{2} \mathrm{O}_{3}$ particle stream hit the surface at an angle of $90^{\circ}$. Blasting of each disc was performed with repeated horizontal movements during a $10 \mathrm{~s}$ period.

- Sandblasted \& $\mathbf{T i O}_{2}$ coated surfaces (SC): $\mathrm{TiO}_{2}$ coated sandblasted $\mathrm{Ti}$ discs. $\mathrm{Al}_{2} \mathrm{O}_{3}$ particles of $800 \mu \mathrm{m}$ grain size under a pressure of 6 bars were used for sandblasting; $\mathrm{TiO}_{2}$ films were deposited in $100 \% \mathrm{O}_{2}$ environment using a pure Ti cathode. The $\mathrm{O}_{2}$ gas flow was adjusted by independent mass flow controllers and the total pressure was maintained at $7.5 \mathrm{mTorr}$ by setting the total gas flow rate to $60 \mathrm{sccm}$ during the deposition process. Coating was conducted in an Arc-PVD unit (Model NVT-12, Novatech-SIE, Moscow, Russia). Experimental conditions were as follows: arc current, $50 \mathrm{~A}$; cathode substrate distance, $250 \mathrm{~mm}$; deposition 
time, $10 \mathrm{~min}$. Samples were produced with a magnetic focusing having a magnitude of $7.92 \mathrm{mT}$. S discs were sputtered before each deposition process for heating the surface and removing the oxide layer from the surface.

- Sandblasted \& acid etched surfaces (SE): Acid etched sandblasted Ti discs. $\mathrm{Al}_{2} \mathrm{O}_{3}$ particles of $800 \mu \mathrm{m}$ grain size under a pressure of 6 bars were used for sandblasting. $10 \%$ oxalic acid at $90^{\circ} \mathrm{C}$ for 20 min was used to generate SE surfaces.

\subsection{Cleaning and Sterilization of the Discs}

After surface preparation, the $\mathrm{P}$ and $\mathrm{S}$ discs were washed in acetone and detergent for 15 and 5 min, respectively. These discs were then rinsed thoroughly in distilled water and propanol ultrasonically. To avoid or minimize changes in surface texture after processing, SC and SE discs were not subjected to this cleaning process. These two surfaces were thought to be clean in terms of their surface preparation methods. The discs were contained in a desiccator between the different surface treatment intervals. All of the discs were sealed with autoclave packets and sterilized by gamma radiation $(25 \mathrm{kGy})$ before cell culture test.

\subsection{Surface Characterization}

Surface morphologies of the discs were characterized quantitatively by a non-contacting optical profilometer (Perthometer S8P, Perthen-Mahr, Göttingen, Germany) which had a laser beam that is $1 \mu$ m in spot diameter. Each sample was measured at one site. 20 scans were performed over a measuring area of $1.750 \times 1 \mathrm{~mm}$ at a scan rate of $0.5 \mathrm{~mm} / \mathrm{s}$. Vertical resolution was $25 \mu \mathrm{m}$ and horizontal resolution was $250 \mu \mathrm{m}$ for all measurements. A Gaussian filter was used to exclude form and waviness from roughness. The size of the filter was set to $50 \times$ $50 \mu \mathrm{m}$. Two height-descriptive parameters as $\mathrm{R}_{\mathrm{a}}$ and $\mathrm{R}_{\mathrm{z}}$ were used to quantify the surface roughness.

SEM (JSM5410, JEOL, Tokyo, Japan) was employed in order to characterize the surface morphology of the discs at a $10 \mathrm{kV}$ acceleration voltage and $\times 350$ magnification.

The crystalline structures of the coatings were characterized by X-ray diffraction (XRD). Analyses were carried out on modified surfaces using a Philips PW 3710 diffractometer, with $\mathrm{Cu}-\mathrm{K} \alpha$ radiation and a graphite monochromator, operated at $20 \mathrm{kV}$ and $10 \mathrm{~mA}$. The samples were measured from $20^{\circ}$ to $80^{\circ} \theta$ with a step size of $0.01^{\circ} 2 \theta \mathrm{min}^{-1}$.

\subsection{Cell Culture and Data Analysis}

Human fetal osteoblast cells (CRL 11372, ATCC American Type Culture Collection, Manassas, VA, USA) were used for the cell adhesion experiments in this study and the experiments were performed in the Department of Histology and Embriology, Istanbul Medical Faculty, Istanbul University (Istanbul, Turkey). Cells were cultured in DMEM-F12 medium supplemented with penicillin (100 units/ml) and streptomycin $(100 \mu \mathrm{g} / \mathrm{ml})$, L-Glutamine $(2.5 \mathrm{mM})$, HEPES buffer $(15 \mathrm{mM})$, sodium pyruvate $(0.5 \mathrm{mM})$, sodium bicarbonate $(1.2 \mathrm{~g} / \mathrm{L})$, G418 sulphate $(0.3 \mathrm{mg} / \mathrm{ml}), 10 \%$ fetal calf serum in $25 \mathrm{~cm}^{2}$ flasks. The cells were allowed to adhere on the substrates at $34^{\circ} \mathrm{C}$ in a humidified atmosphere of $5 \% \mathrm{CO}_{2}\left(\mathrm{CO}_{2}\right.$ Incubator MCO-17AI, Sanyo, Japan). Medium were changed every 3 days and they were subcultured ( $0.25 \%$ trypsin). All tests were performed at the fourth or fifth subculture. The cells were counted and the concentration was adjusted to $1 \times 10^{5}$ cells $/ \mathrm{ml}$ with $100 \%$ viability. The discs were placed in sterile six-well plates. A specially made titanium forceps were used to hold the discs to prevent any contamination of the surfaces by other metals. On every sample, $50 \mu \mathrm{l}$ of a cell suspension was applied and the cells were allowed to attach for 60 minutes to the underlying substrate, afterwards $1 \mathrm{ml}$ of culture medium was added into each well. Cells grown on glass discs were used as Control Group (CG) for the cell culture assay. Cell adhesion on each surface at $24 \mathrm{~h}$ from plating was measured by counting the cells in a hemocytometer after trypsinization at the end of $24 \mathrm{~h}$.

\subsection{Morphological Analysis}

SEM was employed in order to evaluate cell morphologies after the $24 \mathrm{~h}$ cell adhesion assay. Washed samples containing cell layers were fixed with $2.5 \%$ glutaraldehyde in $0.1 \mathrm{M}$ cacodylate buffer $(\mathrm{pH} 7.4)$ for $1 \mathrm{~h}$ at $4{ }^{\circ} \mathrm{C}$. Cells were washed twice for $10 \mathrm{~min}$ with $0.1 \mathrm{M}$ sodium cacodylate buffer and post-fixed in $1 \%$ osmium tetraoxide for $1 \mathrm{~h}$ at $4^{\circ} \mathrm{C}$. Cells were dehydrated stepwise in graded acetone series and incubated in amyl acetate. The 
samples were critical-point dried, sputter-coated with gold-palladium and then viewed under a SEM (JSM5200, JEOL, Tokyo, Japan) at an accelerating voltage of $20 \mathrm{kV}$ and various magnifications.

\subsection{Statistical Evaluation}

All measurements were done four times and expressed in mean \pm standard deviations. The difference between the means for each group was analyzed for statistical significance by Kruskal-Wallis test followed by Post Hoc LSD test comparisons using SPSS 10.0 (SSPS Inc., Chicago, IL, USA) software program. Statistical significance was considered at a probability $P<0.05$.

\section{Results}

\subsection{Surface Characterization}

The $R_{a}$ and $R_{z}$ values referring to the quantitative surface roughness measurements for each of the four types of surfaces are presented at the Figure 1 and Figure 2. Their computerized images for these measurements are displayed in Figure 3. The P surfaces had the lowest deviation in height among the four types of surfaces. The SE surfaces demonstrated the highest increase in $R_{a}$ values while $S$ surfaces demonstrated the highest increase in $R_{z}$ values.

The morphology and the texture of these surfaces are illustrated by scanning electron micrographs presented in Figure 4. Only a few scratching marks remaining from grinding and polishing process are visible on the $\mathrm{P}$ discs without showing orientation. Surface contaminants originating from lubricating fluids used in machining tools were seen as dark spots on these micrographs (Figure 4(a)).

Coarse blasting process of the $\mathrm{P}$ discs with the grain size of $800 \mu \mathrm{m} \mathrm{Al} \mathrm{O}_{3}$ particles showed an aggressive surface deformation with pits on the order of $1-10 \mu \mathrm{m}$. Qualitative analysis with the SEM micrographs presented the blasted discs as the roughest surfaces among all the surfaces. Impact of the $800 \mu \mathrm{m} \mathrm{Al}_{2} \mathrm{O}_{3}$ particles hitting the surface had created smooth spots of $5-50 \mu \mathrm{m}$ width. These surfaces presented many embedded $\mathrm{Al}_{2} \mathrm{O}_{3}$ particles, which have not been eliminated after ultrasonic cleaning process (Figure 4(b)).

SEM micrographs of the $\mathrm{TiO}_{2}$ film coated surfaces appeared rough in topography and were characterized by numerous scattered droplets of $\mathrm{TiO}_{2}$ layer, which have spread onto the sandblasted surface topography. This layer was observed to soften the sharp profile of the hills and shallow the deep valleys by filling into them. $\mathrm{Al}_{2} \mathrm{O}_{3}$ particles were also coated with $\mathrm{TiO}_{2}$ layer (Figure 4(c)).

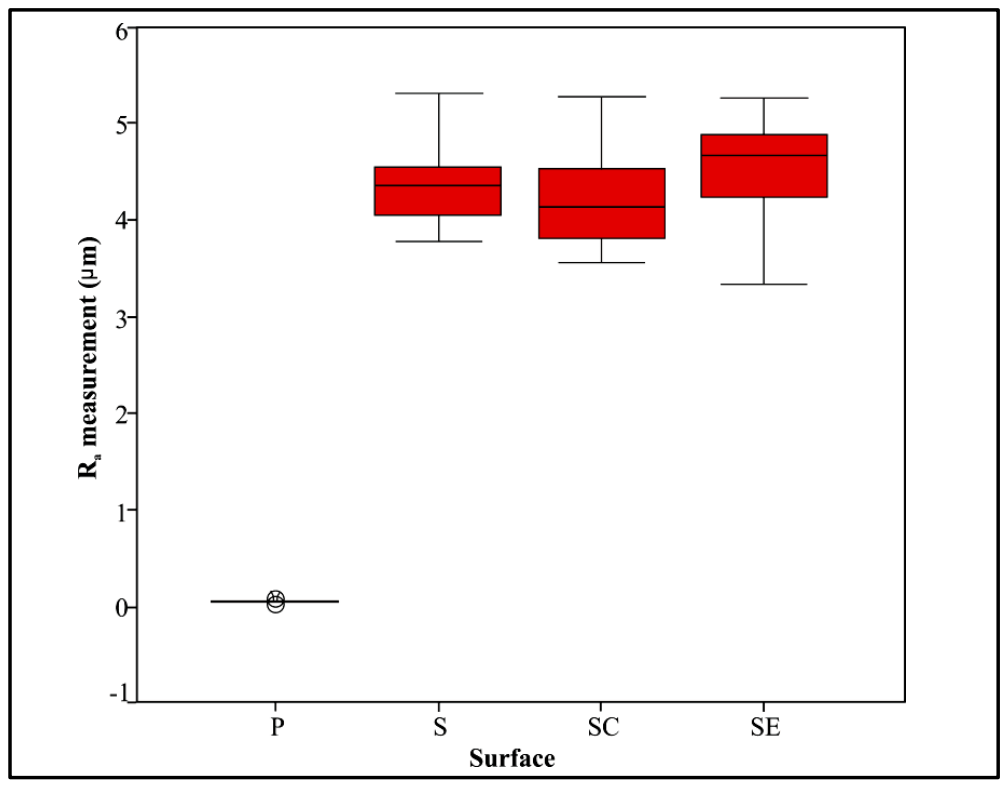

Figure 1. $\mathrm{R}_{\mathrm{a}}$ (avarage roughness) surface roughness assessment of the Polished (P), Sandblasted (S), Sandblasted \& $\mathrm{TiO}_{2}$ coated (SC), and Sandblasted \& acid etched $(\mathrm{SE})$ surfaces. Data are reported as mean $\pm \mathrm{SD}$. 


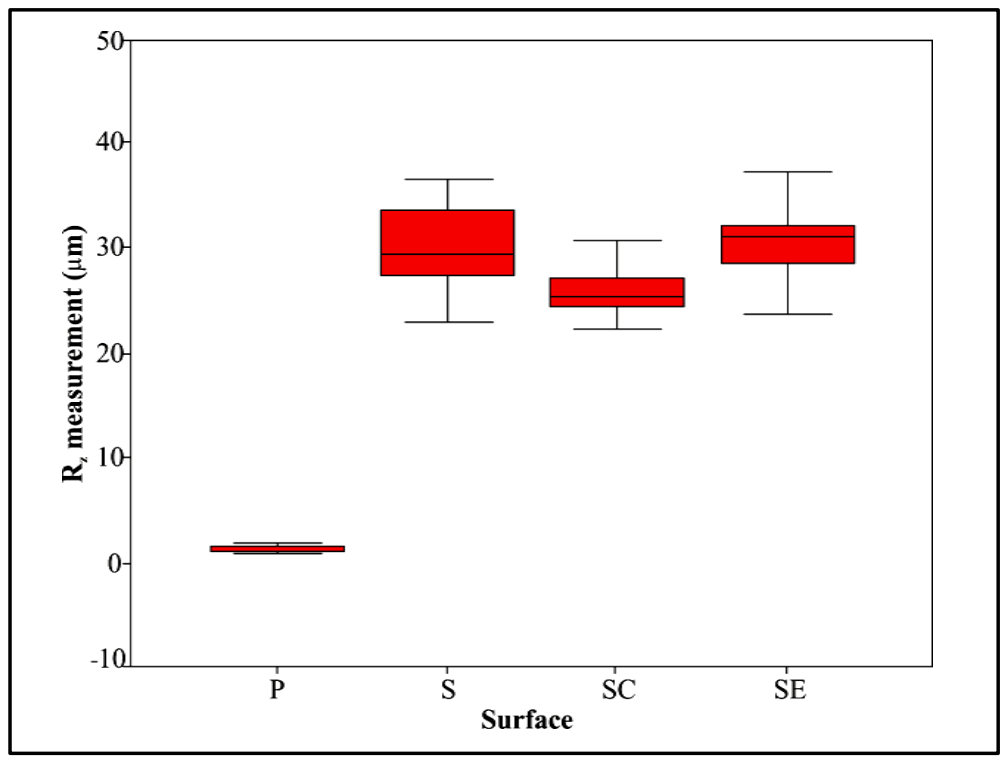

Figure 2. $\mathrm{R}_{\mathrm{z}}$ (mean roughness depth) surface roughness assessment of the Polished (P), Sandblasted (S), Sandblasted \& $\mathrm{TiO}_{2}$ coated (SC), and Sandblasted $\&$ acid etched (SE) surfaces. Data are reported as mean $\pm \mathrm{SD}$.
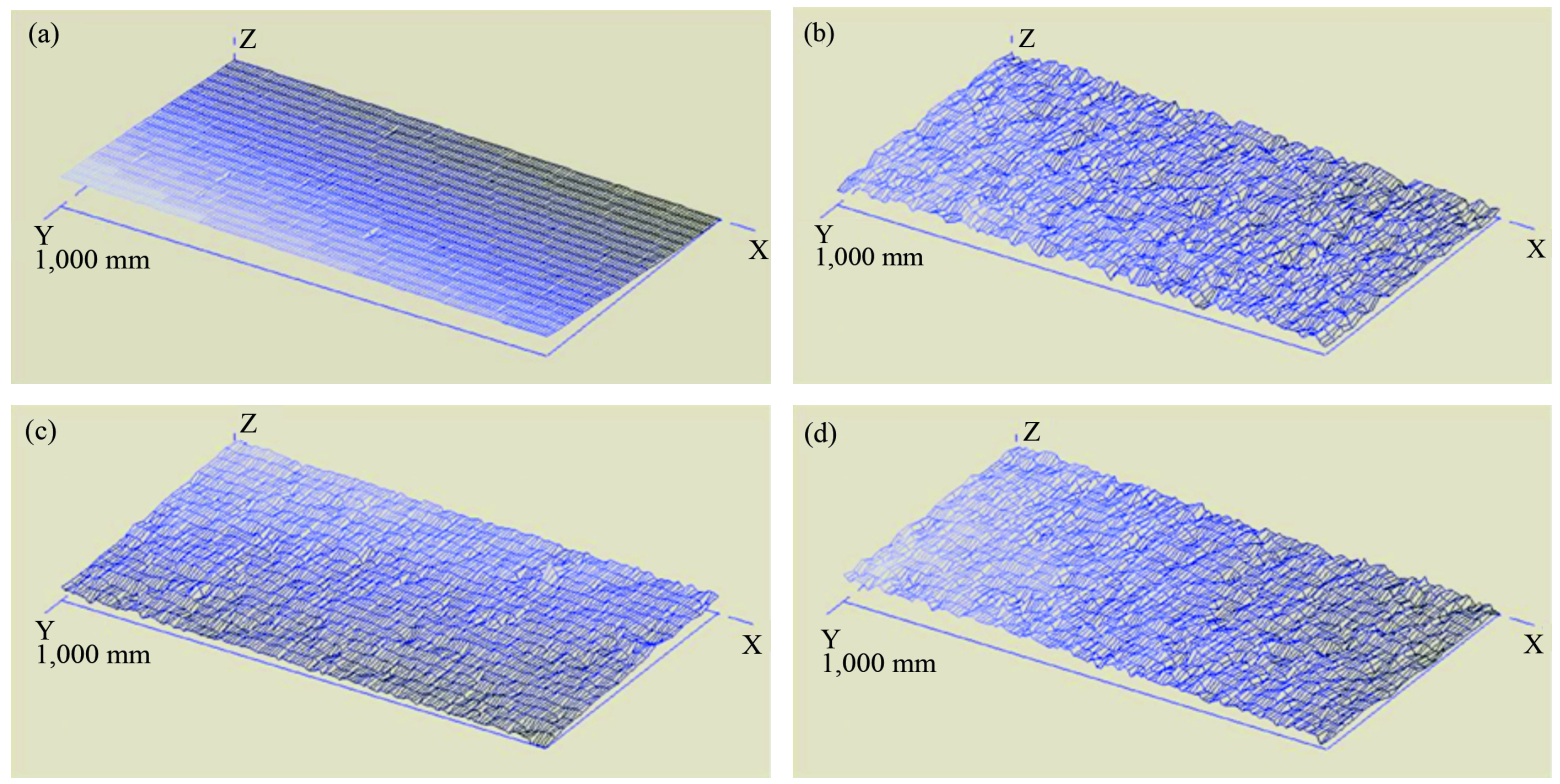

Figure 3. Computer generated topography images of the (a) Polished, (b) Sandblasted, (c) Sandblasted \& $\mathrm{TiO}_{2}$ coated, (d) Sandblasted \& acid etched surfaces.

Oxalic acid etching of the S surfaces created a $0.5 \mu \mathrm{m}$ pitted microtopography at the SE surfaces coinciding onto the macrotopography of the $\mathrm{S}$ surfaces. Etching with oxalic acid solution was not able to dislodge the embedded $\mathrm{Al}_{2} \mathrm{O}_{3}$ particles from the $\mathrm{S}$ surfaces (Figure 4(d)).

XRD patterns of the modified surfaces are shown in Figure 5. P surfaces were composed of pure titanium (Figure 5(a)). XRD patterns of the $\mathrm{S}$ surfaces consisted of $\mathrm{Al}_{2} \mathrm{O}_{3}$ and Ti peaks (Figure 5(b)). Coating the sandblasted surfaces with $\mathrm{TiO}_{2}$ revealed intense peaks of $\mathrm{Ti}$ and anatase, where minute amounts of rutile and TiO were observed in these SC surfaces (Figure 5(c)). Etching the sandblasted surfaces with oxalic acid at the SE surfaces created peaks of Ti and $\mathrm{TiH}_{2}$ (Figure 5(d)). Meanwhile, no phases of $\mathrm{Al}_{2} \mathrm{O}_{3}$ were detected at the $\mathrm{SC}$ and SE surfaces. 

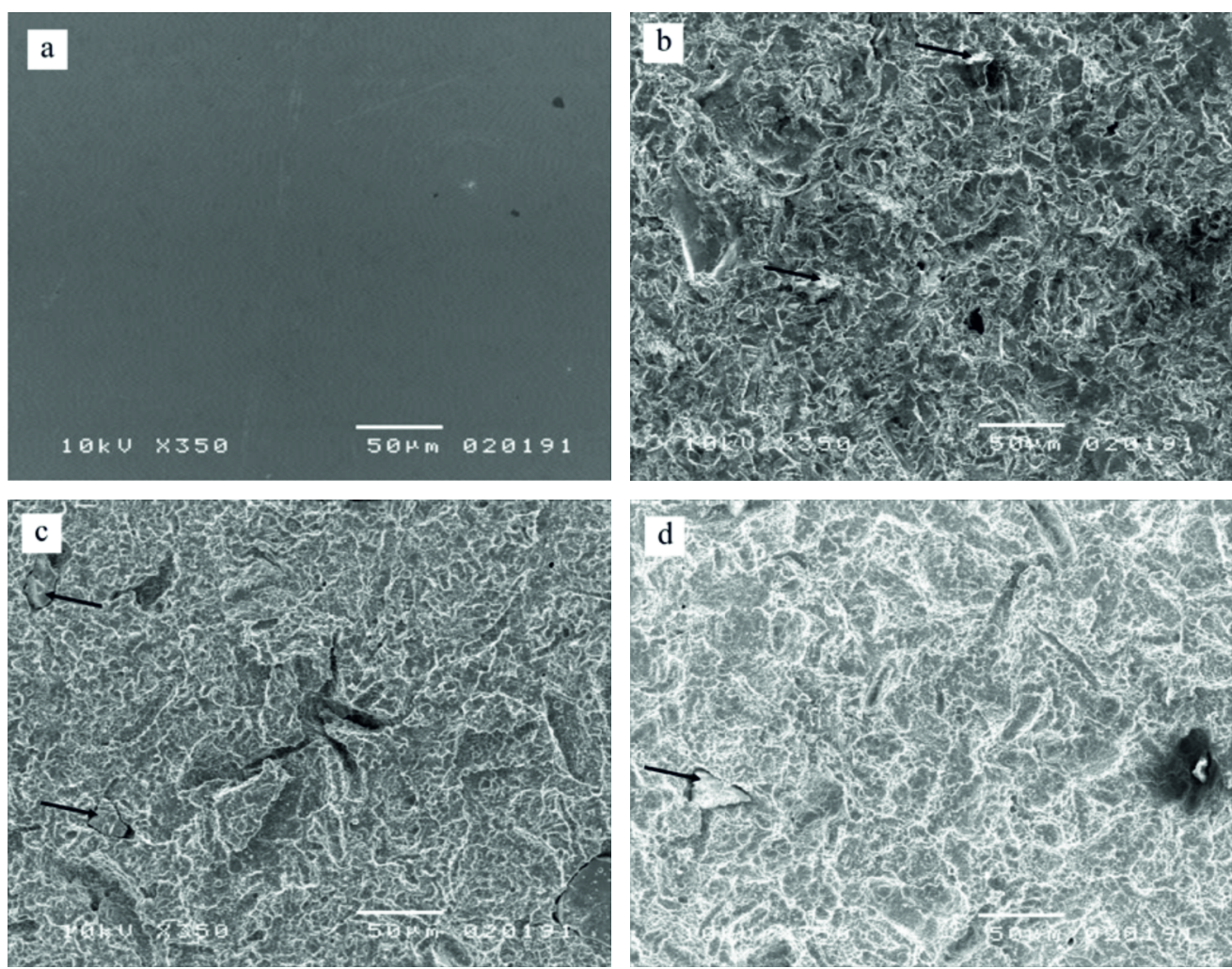

Figure 4. Scanning electron micrographs of the (a) Polished surface, (b) Sandblasted surface, embedded $\mathrm{Al}_{2} \mathrm{O}_{3}$ particles (arrow), (c) Sandblasted \& $\mathrm{TiO}_{2}$ coated surface, embedded $\mathrm{Al}_{2} \mathrm{O}_{3}$ particles coated with $\mathrm{TiO}_{2}$ (arrow), (d) Sandblasted \& acid etched surface, embedded $\mathrm{Al}_{2} \mathrm{O}_{3}$ particles (arrow) (original magnification $\times 350$ and bar $=50 \mu \mathrm{m}$ except where stated).

\subsection{Cell Adhesion and Morphological Evaluation}

After $24 \mathrm{~h}$ of culture, cellular adhesion differed significantly between the modified surfaces $(P=0.0001)$. The results were presented in Figure 6. When the different surface modified groups were compared, both the CG and $\mathrm{S}$ discs presented significantly higher mean total cell counts compared to the other surfaces. Cells had spread well on all titanium samples at the SEM micrographs (Figure 7). P and S surfaces as well as the CG were able to form a confluent monolayer, indicating good adhesion. Variations between cellular morphology were observed between the four different surfaces. Inspection of the deeper metal surface exposed by artificial ruptures in the matrix was shown in Figure 7(a) and Figure 7(b). Cells followed the underlying topographical structure of the SC and SE surfaces by the formation of an oriented adhesion along the hills and valleys of these surfaces. The amounts of cells on SC and SE surfaces were shown to be less dense than that on P and S surfaces. Neighboring cells in all surfaces were shown to maintain physical contact with each other through their multiple cytoplasmic extensions (Figure 7). SEM micrographs of CG showed perfect confluency and some cells that are at the interphase and mitosis stages of their cell cycle were observed at these micrographs (Figure 7(e)).

\section{Discussion}

Through understanding of the dental implant surfaces and cellular interactions, there can be a better way of developing more active dental implants. In vitro cell behavior is oriented by the morphology and composition of the modified titanium surfaces. In vitro cytotoxicity tests are the first step of the screening tests by which a toxic material is eliminated at the initial step allowing the other test materials to proceed to further, more expensive, sophisticated, and time consuming testing methods [28]. In vitro models highlighted the cellular mechanisms better than the in vivo models and the clinical studies. Nontransformed cell lines, osteosarcoma cell lines and intentionally immortalized cell lines may reflect the approach of the in vitro osteoblast-like cell culture models in 


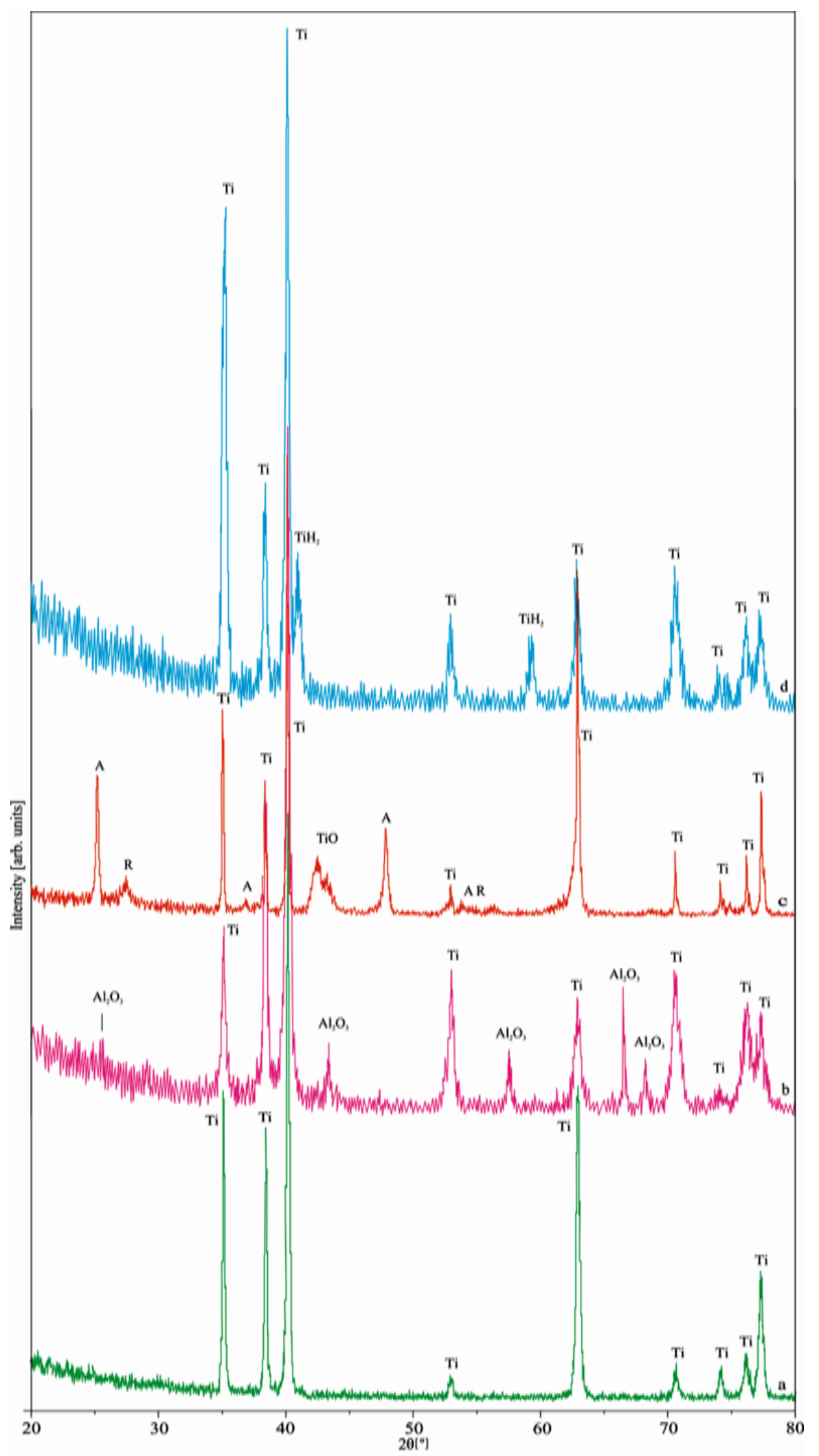

Figure 5. XRD patterns of (a) Polished, (b) Sandblasted, (c) Sandblasted \& $\mathrm{TiO}_{2}$ coated, (d) Sandblasted \& acid etched surfaces. A: Anatase, R: Rutile. 


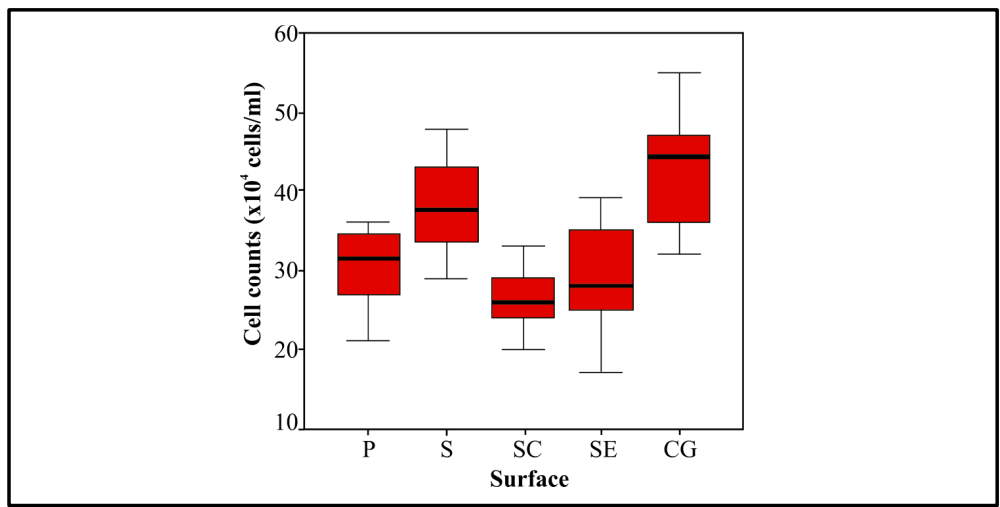

Figure 6. Effects of the Polished (P), Sandblasted (S), Sandblasted \& $\mathrm{TiO}_{2}$ coated (SC), Sandblasted \& acid etched (SE) surfaces and the control group (CG) on CRL-11372 cell yield after culturing for $24 \mathrm{~h}$. Data are reported as mean $\pm \mathrm{SD}$.
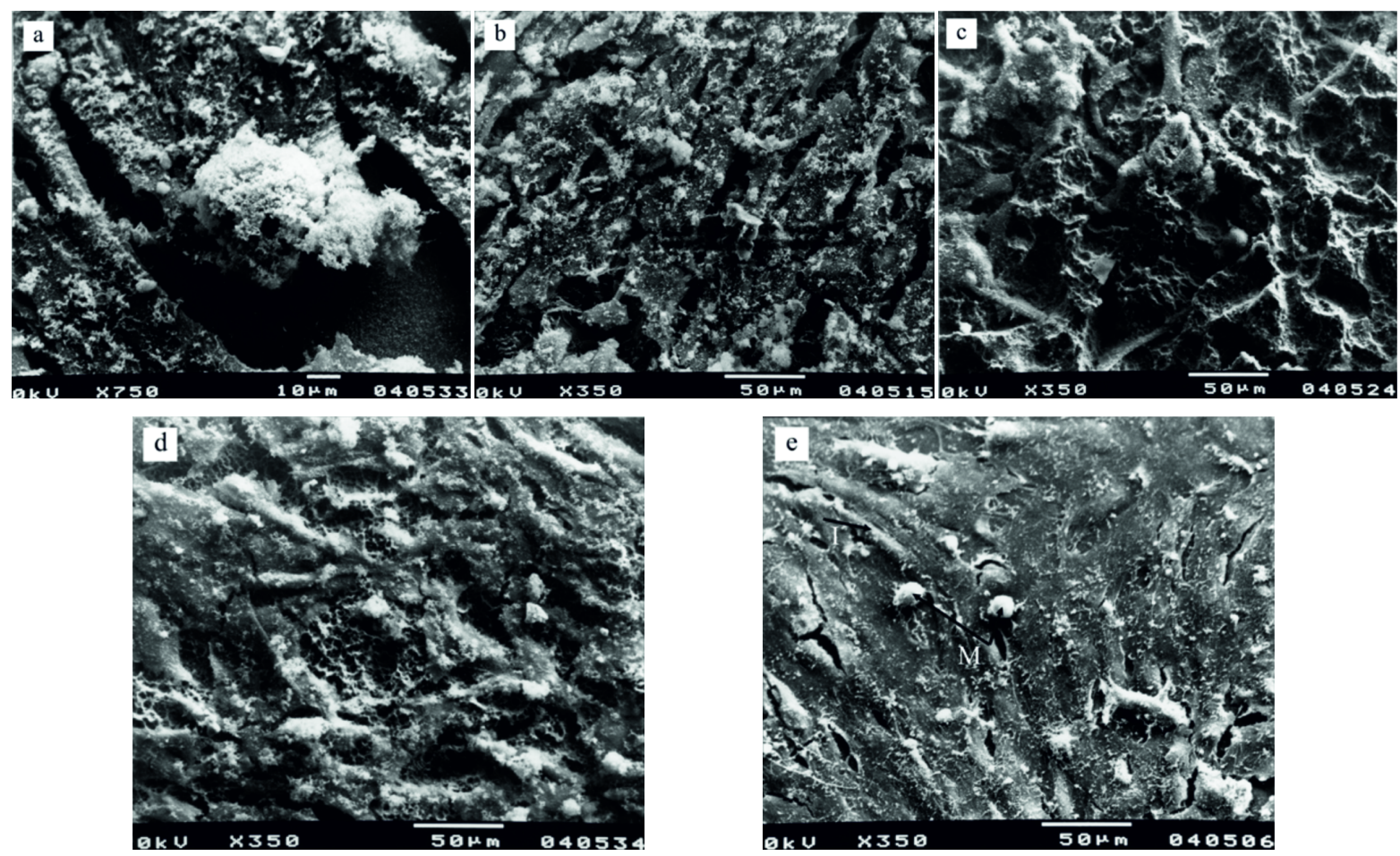

Figure 7. Scanning electron micrographs showing morphology of CRL-11372 cells cultured for $24 \mathrm{~h}$ on the (a) Polished surface (original magnification $\times 750$; bar $=10 \mu \mathrm{m}$ ), (b) Sandblasted surface (original magnification $\times 350 ;$ bar $=50 \mu \mathrm{m}$ ), (c) Sandblasted \& $\mathrm{TiO}_{2}$ coated surface (original magnification $\times 350$; bar $=50 \mu \mathrm{m}$ ), (d) Sandblasted \& acid etched surface (original magnification $\times 350$; bar $=50 \mu \mathrm{m}$ ), (e) Control group; I: Interphase stage (arrow), M: Mitosis stage (arrow) (original magnification $\times 350$; bar $=50 \mu \mathrm{m})$.

a disregulated adhesion, proliferation and differentiation pattern [15] [22] [29]-[34]. In this study, CRL-11372 had been cultured onto the created titanium surfaces in order to mimic normal osteoblast cell lines' responses as had been used in some earlier studies in a similar fashion [35] [36].

Cell attachment is the initial phase of proliferation and differentiation consequently leading to osseointegration [37]. Understanding the mechanisms underlying the concept of osseointegration requires knowledge of cell attachment, migration, growth and differentiation as well as secretion of extracellular matrix to different titanium surfaces. Cell culture systems are excellent models for studying these complex events [10]. Culturing methodology of the osteoblast cells affects the outcomes of the experiments. Vertical or horizontal leveling of the 
specimens' surface and method of inoculating the cell suspension onto the specimens play a key factor in the cell culture experiments [27] [38]. In our study, titanium discs were first placed into wells and the cell suspension was incubated on these surfaces before the medium had been added to the wells similar to a previous study [39]. By this method, cells initially incubated on the surfaces were tried to get protected from the probable drop down to the well bottom. But, this effort was not sufficient to upgrade the initial cell adhesion on the P surfaces when compared with the S surfaces (Figure 6). This finding was in accordance with the results reported by Yang et al. [31] who claimed that, compared to cells on porous surfaces some cells on dense surfaces had easily dropped down to the well bottom from the $2 \mathrm{~mm}$-thick-plate samples while placing the cells onto them. This emphasizes the need for more other methodical precautions to be taken to prevent the drop down of the cells to the well bottom during the cell culture assays.

Seeding concentration was set to $1 \times 10^{5}$ cells $/ \mathrm{ml}$ to assure that the cells do not influence other's orientation behavior by getting into contact with each other [6] [40]. Our morphological observations of CRL-11372 cells evaluated by SEM did not indicate any cytotoxic effect. Cells were undamaged and they exhibited well-arranged cytoplasmic extensions, providing visual evidence of adhesion over these modified titanium surfaces in compliance with the previous studies [41] [42]. CRL-11372 cells on the SC and SE surfaces were intimately adapted to the underlying surface topography morphologically (Figure 7(c) and Figure 7(d)). Although mean total cell counts of these surfaces were lower than P and S surfaces, more intimate cell-surface contacts were obtained on these surfaces (Figure 6, Figure 7(c), and Figure 7(d)). These findings are in consistency with the parameter called "adhesion power" at which it is observed that human osteoblast-like cells were supposed to be more sensitive to the organization and morphology of roughness rather than to amplitude [43]. Contrary to these findings, $\mathrm{P}$ and $\mathrm{S}$ surfaces avoided contacting bodily to the underlying surface topography. Cells on the P surfaces relatively lacked anchorage and they spread slowly (Figure 7(a)). The ruptures in the cell matrixes were artifacts mostly seen at the other studies resulting in due to shrinkage of cells during the drying procedure of the specimen's preparation [10] [42] [44]. Rough S surfaces with unordered pits, sharp edges and steep angles seemed to divert the cells' adhesion behavior constraining them to attach by their cytoplasmic extensions to the available sites on the surface and to the neighboring cells (Figure 7(b)). These findings are in agreement with the data of Lumbikanonda and Sammons [45] who had notified that osteoblast-like cells lacked adaptation to polished surfaces, where on rough TPS surfaces these cells spanned over the surface, creating spaces or gaps underneath. In this regard, Lange et al. [15] concluded in their study that large grain sized corundum blasted surfaces exhibited cell morphologies bridging the valleys and they attached only with their extensions to the hills limiting their surface area attaching to the underlying substrate.

At literature, particle sizes used in sand blasting processes generally don't exceed $600 \mu \mathrm{m}$ and the application forces vary between 3 - 6 bars [41] [46]-[48]. In this study, $800 \mu \mathrm{m}$ of particle size and an applied pressure of 6 bars had created aggressively roughened surface profiles. The coarsest surfaces among the four surfaces were the SE surfaces that were sandblasted with $800 \mu \mathrm{m}$ particles and etched with oxalic acid. S surfaces showing coarse pits on the order of $1-10 \mu \mathrm{m}$ have been smoothened by the acid etching process to add a $0.5 \mu \mathrm{m}$ pitted topography over the existing surface topography (Figure 4(b) and Figure 5(d)). Although no significant differences were found between the $R_{a}$ and $R_{z}$ values between the $S$ and SE surface, SEM image analyses represented different surface morphologies (Figure 1, Figure 2, Figure 4(b), and Figure 5(d)). In a similar fashion, Mustafa et al. [49] reported that after sandblasting with $106-180 \mu \mathrm{m}$ and $180-300 \mu \mathrm{m}$ sized particles, the created surfaces had presented different surface homogeneity at their SEM micrographs contrary to their similar surface roughness values. This marked the need for quantitative evaluation methods as well as complementary qualitative evaluation methods when characterizing a surface topography.

$\mathrm{S}$ surfaces had shown significantly higher mean total cell counts than the P, SE and SC titanium surfaces (Figure 6). But, in terms of $\mathrm{R}_{\mathrm{a}}$ values no significant difference was found at this surface compared to the $\mathrm{SE}$ and $\mathrm{SC}$ surfaces. Similarly, in terms of $\mathrm{R}_{\mathrm{z}}$ values no significant difference was found at this surface compared to the SE surfaces (Figure 2). The mean total cell counts of adherent cells were not affected by surface roughness. Mustafa et al. [49] claimed that [3H]-thymidine incorporation into the osteoblast-like cells had increased with increasing surface roughness values, indicating DNA synthesis to be surface roughness dependent. On the contrary to these studies; Lauer et al. [50] confirmed our suggestions in their study, claiming that the roughness of the titanium surfaces didn't affect the behavior of the osteoblast-like cells. Rosa and Beloti [51] repoted that cpTi blasted with 25-, 75-, and 250- $\mu \mathrm{m}$ of $\mathrm{Al}_{2} \mathrm{O}_{3}$ particles would optimize osteoblastic differentiation by rat bone marrow cells, including reduced cell proliferation and increased ALP activity and bone-like nodule formation, 
while surface roughness would not affect cell attachment significantly. The time scale; $2 \mathrm{~h}$, as used in this evaluation, was suggested as a short time for evaluating cell attachment.

Surface chemistry and/or microcrystallinity of Ti and Ti-6Al-4 V was found to have an early influence on the cellular differentiation of human bone derived cells [52]. Anselme et al. [53] reported that the differences between polished and sandblasted surfaces at their experiments weren't related neither to Ti6Al4V substrates roughness nor to surface chemistry alterations. Wennerberg et al. [46] observed no negative effects resulting from the aluminum ions found on the implant surface following the sandblasting procedure. Similarly, sandblasting with $\mathrm{Al}_{2} \mathrm{O}_{3}$ particles didn't negatively affect the mean total cell counts of the $\mathrm{S}$ surface which had high peaks of $\mathrm{Al}_{2} \mathrm{O}_{3}$ at the XRD of these samples.

Titanium oxide layers produced on samples with cytotoxic components were found to shield the cells from toxic alloying elements, with the result that the cell reaction is influenced only by the thin titanium oxide surface layer and not by the composition of the bulk material [30]. Minor variations in substrate composition and topography were found to exhibit significant differential osteoblast responses to cpTi grades 1 and 4 [54]. At the SE surfaces these $\mathrm{Al}_{2} \mathrm{O}_{3}$ particles were coated with titanium oxide layer (Figure 5). Since the $\mathrm{Al}_{2} \mathrm{O}_{3}$ didn't act cytotoxic, titanium oxide layer at the SC surface acted as a new surface layer for the cell responses which showed lower mean total cell counts (Figure 6). SE surfaces displayed embedded $\mathrm{Al}_{2} \mathrm{O}_{3}$ particles where at their XRD no $\mathrm{Al}_{2} \mathrm{O}_{3}$ peak was observed depending on the area measured at the XRD (Figure 5). The surface mostly included $\mathrm{Ti}$ and $\mathrm{TiH}_{2}$ peaks originating from the oxalic acid etching. These $\mathrm{TiH}_{2}$ peaks acted more biocompatible than the titanium oxide peaks of anatase and rutile. This detrimental effect may be attributed to the probable photocatalytical activity of the anatase peak present at the $\mathrm{SC}$ surfaces (Figure 5). $\mathrm{TiO}_{2}$ exhibit significant cytotoxicity and potential photogenotoxicity under UV light irradiation [55]. During the cell culture assay stages at the laminar hood under UV light, anatase form of $\mathrm{TiO}_{2}$ over the SC surfaces may have presented photocatalytical effect over the cells incubated onto them lowering the mean total cell counts for these surfaces.

\section{Conclusions}

CRL-11372 cell culture system permits a reproducible examination for investigating the biocompatibility of dental implant materials in vitro. We have to conclude that our in vitro study could not clearly confirm an effect of surface roughness and composition on the morphology and adhesion of CRL-11372 cells cultured on surfaces. Further studies with additional assays may be needed to clarify the issues arising from the experiment results for interpretation of the cell physiology over the biomaterials.

All research within this study has been done in vitro. No section or portion of the work has yet been tested in vivo. This thus allows the work to conform to the ethical principles presented in the Helsinki Declaration of 1975, placing the patient's health in topmost priority, by performing initial testing on in vitro specimen.

\section{Acknowledgements}

Preparation and characterization of the commercially pure titanium metal surfaces in this study were supported by The Research Support Unit of Istanbul University as the project no 1749/21122001. The authors thank the Dentsply Friadent ${ }^{\circledR}$ (Mannheim, Germany) for providing the cp Ti discs.

\section{References}

[1] West, J.D. and Oates, T.W. (2007) Identification of Stability Changes for Immediately Placed Dental Implants. The International Journal of Oral \& Maxillofacial Implants, 22, 623-630.

[2] Payer, M., Kirmeier, R., Jakse, N., Wimmer, G., Wegscheider, W. and Lorenzoni, M. (2008) Immediate Provisional Restoration of XiVE ${ }^{\circledR}$ Screw-Type Implants in the Posterior Mandible. Clinical Oral Implants Research, 19, 160-165. http://dx.doi.org/10.1111/j.1600-0501.2007.01268.x

[3] Abboud, M., Koeck, B., Stark, H., Wahl, G. and Paillon, R. (2005) Immediate Loading of Single-Tooth Implants in the Posterior Region. The International Journal of Oral \& Maxillofacial Implants, 20, 61-68.

[4] Cooper, L., Felton, D.A., Kugelberg, C.F., Ellner, S., Chaffe, N., Molina, A.L., Moriarty, J.D., Paquette, D. and Palmqvist, U. (2001) A Multicenter 12-Month Evaluation of Single-Tooth Implants Restored 3 Weeks after 1-Stage surgery. The International Journal of Oral \& Maxillofacial Implants, 16, 182-192.

[5] Schwartz, Z. and Boyan, B.D. (1994) Underlying Mechanisms at the Bone-Biomaterial Interface. Journal of Cellular Biochemistry, 56, 340-347. http://dx.doi.org/10.1002/jcb.240560310 
[6] Orsini, G., Assenza, B., Scarano, A., Piattelli, M. and Piattelli, A. (2000) Surface Analysis of Machined versus Sandblasted and Acid-Etched Titanium Implants. The International Journal of Oral \& Maxillofacial Implants, 15, 779-784.

[7] Masaki, C., Schneider, G.B., Zaharias, R., Seabold, D. and Stanford, C. (2005) Effects of Implant Surface Microtopography on Osteoblast Gene Expression. Clinical Oral Implants Research, 16, 650-656. http://dx.doi.org/10.1111/j.1600-0501.2005.01170.x

[8] Lim, Y.J., Oshida, Y., Andres, C.J. and Barco, M.T. (2001) Surface Characterizations of Variously Treated Titanium Materials. The International Journal of Oral \& Maxillofacial Implants, 16, 333-342.

[9] Müeller, W.D., Gross, U., Fritz, T., Voigt, C., Fischer, P., Berger, G., Rogaschewski, S. and Lange, K.P. (2003) Evaluation of the Interface between Bone and Titanium Surfaces Being Blasted by Aluminium Oxide or Bioceramic Particles. Clinical Oral Implants Research, 14, 349-356. http://dx.doi.org/10.1034/j.1600-0501.2003.00791.x

[10] Mustafa, K., Wroblewski, J., Hultenby, K., Lopez, B.S. and Arvidson, K. (2000) Effects of Titanium Surfaces Blasted with $\mathrm{TiO}_{2}$ Particles on the Initial Attachment of Cells Derived from Human Mandibular Bone. A Scanning Electron Microscopic and Histomorphometric Analysis. Clinical Oral Implants Research, 11, 116-128. http://dx.doi.org/10.1034/j.1600-0501.2000.011002116.x

[11] Cooper, L.F., Masuda, T., Whitson, S.W., Yliheikkilä, P. and Felton, D.A. (1999) Formation of Mineralizing Osteoblast Cultures on Machined, Titanium Oxide Grit-Blasted, and Plasma-Sprayed Titanium Surfaces. The International Journal of Oral \& Maxillofacial Implants, 14, 37-47.

[12] Rønold, H.J., Lyngstadaas, S.P. and Ellingsen, J.E. (2003) A Study on the Effect of Dual Blasting with TiO ${ }_{2}$ on Titanium Implant Surfaces on Functional Attachment in Bone. Journal of Biomedical Materials Research Part A, 67, 524530. http://dx.doi.org/10.1002/jbm.a.10580

[13] Rønold, H.J. and Ellingsen, J.E. (2002) Effect of Micro-Roughness Produced by $\mathrm{TiO}_{2}$ Blasting-Tensile Testing of Bone Attachment by Using coin-Shaped Implants. Biomaterials, 23, 4211-4219. http://dx.doi.org/10.1016/S0142-9612(02)00167-9

[14] Ivanoff, C.J., Hallgren, C., Widmark, G., Sennerby, L. and Wennerberg, A. (2001) Histologic Evaluation of the Bone Integration of $\mathrm{TiO}_{2}$ Blasted and Turned Titanium Microimplants in Humans. Clinical Oral Implants Research, 12, 128-134. http://dx.doi.org/10.1034/j.1600-0501.2001.012002128.x

[15] Lange, R., Lüthen, F., Beck, U., Rychly, J., Baumann, A. and Nebe, B. (2002) Cell-Extracellular Matrix Interaction and Physico-Chemical Characteristics of Titanium Surfaces Depend on the Roughness of the Material. Biomolecular Engineering, 19, 255-261. http://dx.doi.org/10.1016/S1389-0344(02)00047-3

[16] LeGeros, R.Z., Lin, S., Rohanizadeh, R., Mijares, D. and LeGeros, J.P. (2003) Biphasic Calcium Phosphate Bioceramics: Preparation, Properties and Applications. Journal of Materials Science: Materials in Medicine, 14, 201-209. http://dx.doi.org/10.1023/A:1022872421333

[17] Citeau, A., Guicheux, J., Vinatier, C., Layrolle, P., Nguyen, T.P., Pilet, P. and Daculsi, G. (2005) In Vitro Biological Effects of Titanium Rough Surface Obtained by Calcium Phosphate Grid Blasting. Biomaterials, 26, 157-165. http://dx.doi.org/10.1016/j.biomaterials.2004.02.033

[18] Mazor, Z. and Cohen, D.K. (2003) Preliminary 3-Dimensional Surface Texture Measurement and Early Loading Results with a Microtextured Implant Surface. The International Journal of Oral \& Maxillofacial Implants, 18, 729-738.

[19] Novaes Jr., A.B., Souza, S.L., de Oliveira, P.T. and Souza, A.M. (2002) Histomorphometric Analysis of the Bone-Implant Contact Obtained with 4 Different Implant Surface Treatments Placed Side by Side in the Dog Mandible. The International Journal of Oral \& Maxillofacial Implants, 17, 377-383.

[20] Marinho, V.C., Celletti, R., Bracchetti, G., Petrone, G., Minkin, C. and Piattelli, A. (2003) Sandblasted and AcidEtched Dental Implants: A Histologic Study in Rats. The International Journal of Oral \& Maxillofacial Implants, 18, 75-81.

[21] Anselme, K. and Bigerelle, M. (2005) Topography Effects of Pure Titanium Substrates on Human Osteoblast LongTerm Adhesion. Acta Biomaterialia, 1, 211-222. http://dx.doi.org/10.1016/j.actbio.2004.11.009

[22] Zinger, O., Anselme, K., Denzer, A., Habersetzer, P., Wieland, M., Jeanfils, J., Hardouin, P. and Landolt, D. (2004) Time-Dependent Morphology and Adhesion of Osteoblastic Cells on Titanium Model Surfaces Featuring Scale-Resolved Topography. Biomaterials, 25, 2695-2711. http://dx.doi.org/10.1016/j.biomaterials.2003.09.111

[23] Cho, S.A. and Park, K.T. (2003) The Removal Torque of Titanium Screw Inserted in Rabbit Tibia Treated by Dual Acid Etching. Biomaterials, 24, 3611-3617. http://dx.doi.org/10.1016/S0142-9612(03)00218-7

[24] Cordioli, G., Majzoub, Z., Piattelli, A. and Scarano, A. (2000) Removal Torque and Histomorphometric Investigation of 4 Different Titanium Surfaces: An Experimental Study in the Rabbit Tibia. International Journal of Oral \& Maxillofacial Implants, 15, 668-674.

[25] Thull, R. and Grant, D. (2001) Physical and Chemical Vapor Deposition and Plasma-Assisted Techniques for Coating Titanium. In: Brunette, D.M., Tengvall, P., Textor, M. and Thomsen, P., Eds., Titanium in Medicine, Springer-Verlag 
Berlin Heidelberg, New York, 283-341. http://dx.doi.org/10.1007/978-3-642-56486-4 10

[26] Scotchford, C.A., Ball, M., Winkelmann, M., Vörös, J., Csucs, C., Brunette, D.M., Danuser, G. and Textor, M. (2003) Chemically Patterned, Metal-Oxide-Based Surfaces Produced by Photolithographic Techniques for Studying Proteinand Cell-Interactions. II: Protein Adsorption and Early Cell Interactions. Biomaterials, 24, 1147-1158. http://dx.doi.org/10.1016/S0142-9612(02)00488-X

[27] Araújo, N.S., Jaeger, R.G., Todescan, F.F., Jaeger, M.M.M. and Groll, W. (2001) Cell Culture Test for Assessing Attachment and Proliferation on Titanium Dental Implants with Modified Surfaces. Revista da Pós-Graduação, 8, 103-109.

[28] Schmaltz, G. (1997) Concepts in Biocompatibility Testing of Dental Restorative Materials. Clinical Oral Investigations, 1, 154-162. http://dx.doi.org/10.1007/s007840050027

[29] Eisenbarth, E., Linez, P., Biehl, V., Velten, D., Breme, J. and Hildebrand, H.F. (2002) Cell Orientation and Cytoskeleton Organisation on Ground Titanium Surfaces. Biomolecular Engineering, 19, 233-237. http://dx.doi.org/10.1016/S1389-0344(02)00028-X

[30] Eisenbarth, E., Velten, D., Schenk-Meuser, K., Linez, P., Biehl, V., Duschner, H., Breme, J. and Hildebrand, H. (2002) Interactions between Cells and Titanium Surfaces. Biomolecular Engineering, 19, 243-249. http://dx.doi.org/10.1016/S1389-0344(02)00032-1

[31] Yang, Y., Tian, J., Deng, L. and Ong, J.L. (2002) Morphological Behavior of Osteoblast-Like Cells on Surface-Modified Titanium in Vitro. Biomaterials, 23, 1383-1389. http://dx.doi.org/10.1016/S0142-9612(01)00259-9

[32] Shibata, Y., Hosaka, M., Kawai, H. and Miyazaki, T. (2002) Glow Discharge Plasma Treatment of Titanium Plates Enhances Adhesion of Osteoblast-Like Cells to the Plates through the Integrin-Mediated Mechanism. International Journal of Oral \& Maxillofacial Implants, 17, 771-777.

[33] Matsuura, T., Hosokawa, R., Okamoto, K., Kimoto, T. and Akagawa, Y. (2000) Diverse Mechanisms of Osteoblast Spreading on Hydroxyapatite and Titanium. Biomaterials, 21, 1121-1127. http://dx.doi.org/10.1016/S0142-9612(99)00264-1

[34] Schmalz, G. (1994) Use of Cell Cultures for Toxicity Testing of Dental Materials-Advantages and Limitations. Journal of Dentistry, 22, S6-S11. http://dx.doi.org/10.1016/0300-5712(94)90032-9

[35] Yao, C., Perla, V., Mc Kenzie, J.L., Slamovich, E.B. and Webster, T.J. (2005) Anodized Ti and Ti ${ }_{6} \mathrm{Al}_{4} \mathrm{~V}$ Possessing Nanometer Surface Features Enhances Osteoblast Adhesion. Journal of Biomedical Nanotechnology, 1, 68-73. http://dx.doi.org/10.1166/jbn.2005.008

[36] Schwartz, J., Avaltroni, M.J., Danahy, M.P., Silverman, B.M., Hanson, E.L., Schwarzbauer, J.E., Midwood, K.S. and Gawal, E.S. (2003) Cell Attachment and Spreading on Metal Implant Materials. Materials Science and Engineering: $C$, 23, 395-400. http://dx.doi.org/10.1016/S0928-4931(02)00310-7

[37] Cooper, L.F. (1998) Biologic Determinants of Bone Formation for Osseointegration: Clues for Future Clinical Improvements. Journal of Prosthetic Dentistry, 80, 439-449. http://dx.doi.org/10.1016/S0022-3913(98)70009-5

[38] Sammons, R.L., Lumbikanonda, N., Gross, M. and Chantzler, P. (2005) Comparison of Osteoblast Spreading on Microstructured Dental Implant Surfaces and Cell Behaviour in an Explant Model of osseointegration. A Scanning Electron Microscopy Study. Clinical Oral Implants Research, 16, 657-666. http://dx.doi.org/10.1111/j.1600-0501.2005.01168.x

[39] Ramires, P.A., Giuffrida, A. and Milella, E. (2002) Three-Dimensional Reconstruction of Confocal Laser Microscopy Images to Study the Behaviour of Osteoblastic Cells Grown on Biomaterials. Biomaterials, 23, 397-406. http://dx.doi.org/10.1016/S0142-9612(01)00118-1

[40] Yliheikkila, P.K., Felton, D.A., Whitson, S.W., Ambrose, W.W., Uoshima, K. and Cooper, L.F. (1995) Correlative Microscopic Investigation of the Interface between Titanium Alloy and the Osteoblast-Osteoblast Matrix Using Mineralizing Cultures of Primary Fetal Bovine Mandibular Osteoblasts. International Journal of Oral \& Maxillofacial Implants, 10, 655-665.

[41] Bowers, K.T., Keller, J.C., Randolph, B.A., Wick, D.G. and Michaels, C.M. (1992) Optimization of Surface Micromorphology for Enhanced Osteoblast Responses in Vitro. International Journal of Oral \& Maxillofacial Implants, 7 , 302-310

[42] Knabe, C., Klar, F., Fitzner, R., Radlanski, R.J. and Gross, U. (2002) In Vitro Investigation of Titanium and Hydroxyapatite Dental Implant Surfaces Using a Rat Bone Marrow Stromal Cell Culture System. Biomaterials, 23, 3235-3245. http://dx.doi.org/10.1016/S0142-9612(02)00078-9

[43] Anselme, K. and Bigerelle, M. (2005) Topography Effects of Pure Titanium Substrates on Human Osteoblast LongTerm Adhesion. Acta Biomaterialia, 1, 211-222. http://dx.doi.org/10.1016/j.actbio.2004.11.009

[44] Bagambisa, F.B., Joos, U. and Schilli, W. (1990) Interaction of Osteogenic Cells with Hydroxylapatite Implant Materials in Vitro and in Vivo. International Journal of Oral \& Maxillofacial Implants, 5, 217-226.

[45] Lumbikanonda, N. and Sammons, R. (2001) Bone Cell Attachment to Dental Implants of Different Surface Characte- 
ristics. International Journal of Oral \& Maxillofacial Implants, 16, 627-636.

[46] Wennerberg, A., Albrektsson, T. and Andersson, B. (1996) Bone Tissue Response to Commercially Pure Titanium Implants Blasted with Fine and Coarse Particles of Aluminum Oxide. International Journal of Oral \& Maxillofacial Implants, 11, 38-45.

[47] Nebe, B., Luthen, F., Lange, R., Becker, P., Beck, U. and Rychly, J. (2004) Topography-Induced Alterations in Adhesion Structures Affect Mineralization in Human Osteoblasts on Titanium. Materials Science and Engineering: C, 24, 619624. http://dx.doi.org/10.1016/j.msec.2004.08.034

[48] Wennerberg, A., Ide-Ektessabi, A., Hatkamata, S., Sawase, T., Johansson, C., Albrektsson, T., Martinelli, A., Södervall, U. and Odelius, H. (2004) Titanium Release from Implants Prepared with Different Surface Roughness. Clinical Oral Implants Research, 15, 505-512. http://dx.doi.org/10.1111/j.1600-0501.2004.01053.x

[49] Mustafa, K., Wennerberg, A., Wroblewski, J., Hultenby, K., Lopez, B.S. and Arvidson, K. (2001) Determining Optimal Surface Roughness of $\mathrm{TiO}_{2}$ Blasted Titanium Implant Material for Attachment, Proliferation and Differentiation of Cells Derived from Human Mandibular Alveolar Bone. Clinical Oral Implants Research, 12, 515-525. http://dx.doi.org/10.1034/j.1600-0501.2001.120513.x

[50] Lauer, G., Wiedmann-Al-Ahmad, M., Otten, J.E., Hubner, U., Schmelzeisen, R. and Schilli, W. (2001) The Titanium Surface Texture Effects Adherence and Growth of Human Gingival Keratinocytes and Human Maxillar OsteoblastLike Cells in Vitro. Biomaterials, 22, 2799-2809. http://dx.doi.org/10.1016/S0142-9612(01)00024-2

[51] Rosa, A.L. and Beloti, M.M. (2003) Rat Bone Marrow Cell Response to Titanium and Titanium Alloy with Different Surface Roughness. Clinical Oral Implants Research, 14, 43-48. http://dx.doi.org/10.1034/j.1600-0501.2003.140106.x

[52] Zreiqat, H. and Howlett, C.R. (1999) Titanium Substrata Composition Influences Osteoblastic Phenotype: In Vitro Study. Journal of Biomedical Materials Research, 47, 360-366. http://dx.doi.org/10.1002/(SICI)1097-4636(19991205)47:3<360::AID-JBM10>3.0.CO;2-K

[53] Anselme, K., Linez, P., Bigerelle, M., Le Maguer, D., Le Maguer, A., Hardouin, P., Hildebrand, H.F., Iost, A. and Leroy, J.M. (2000) The Relative Influence of the Topography and Chemistry of TiAl6V4 Surfaces on Osteoblastic Cell Behaviour. Biomaterials, 21, 1567-1577. http://dx.doi.org/10.1016/S0142-9612(00)00042-9

[54] Ahmad, M., Gawronski, D., Blum, J., Goldberg, J. and Gronowicz, G. (1999) Differential Response of Human Osteoblast-Like Cells to Commercially Pure (cp) Titanium Grades 1 and 4. Journal of Biomedical Materials Research, 46, 121-131. http://dx.doi.org/10.1002/(SICI)1097-4636(199907)46:1<121::AID-JBM14>3.0.CO;2-P

[55] Blake, D.M., Maness, P.C., Huang, Z., Wolfrum, E.J., Huang, J. and Jacoby, W.A. (1999) Application of the Photocatalytic Chemistry of Titanium Dioxide to Disinfection and the Killing of Cancer Cells. Separation \& Purification Reviews, 28, 1-50. http://dx.doi.org/10.1080/03602549909351643 